\title{
Disrupting student voice in education research through music
}

Stewart Riddle, Stewart.Riddle@usq.edu.au

School of Teacher Education and Early Childhood, University of Southern Queensland

\begin{abstract}
Education policy in the contemporary context tends to produce reductive, oversimplified and essentialist notions of classrooms, teachers and students. An emphasis on quantifiable big data that provides for 'evidence-based practice' and focus on 'what works' permeates the education machine and limits the boundaries of what can be known. Yet the complex arrangement of policies, politics, philosophies, pedagogies, practices and people that we label the 'classroom' provides for rich study of the multiple ways that pedagogic encounters might be experienced by young people. This paper seeks to engage with the notions of student voice and agency within an alternative context of learning - an urban senior secondary music college. Experimenting in conceptualising classrooms as moments of becoming, music is proposed as a performative method for interrogating notions of student voice.
\end{abstract}

Key words: Music, Student Voice, Deleuze, Postqualitative, Education Research.

\section{Introduction}

$\sim$ I'm not as sociable as most people

The issue of attending to student voice has become oversaturated in contemporary education research, over-valorised (Fielding, 2004), contradictory and potentially rendered meaningless (Thomson, 2011). Yet there remains a seductive, hidden coercion underneath narratives of student voice in the context of wider school improvement discourses (Mockler and Groundwater-Smith, 2014). McLeod (2011) describes how romanticised notions of identity, agency, inclusion and equity permeate student voice, through calls to "rescue and release the voices of the silenced and marginalised" (p. 179). The imperative of improvement in education discourse pervades research that seeks to understand student voice (Mockler and Groundwater-Smith, 2014) and how students might be afforded a more democratic place in their education experiences (Apple \& Beane, 1999). Perhaps education researchers interested in student voice might instead ask: what about the voices that we do not hear and, perhaps more importantly, those voices that we cannot hear?

$\sim$ they don't mention it

The intent of this paper is to contribute to the developing body of work around postqualitative research in education (see Lather and St. Pierre, 2013; MacLure, 2013; Mazzei, 2013; St. Pierre, 
2011) that seeks to establish a refusal space against the neoliberal and neoconservative forces acting upon education policy, practice and research. These forces work in ways that are part of what Deleuze (1992) refers to as the control society, where the social institutions and structures such as schooling are reconstituted as sites of continuous flows of control. However, the complex arrangement of policies, politics, philosophies, pedagogies, practices and people that form the pedagogic encounters of the classroom resist troubling. It is here that student voice has taken hold as a cornerstone of education reform and school improvement narratives. For example, Thomson and Gunter (2006) critique how student voice is used by policy makers to achieve school improvement and attainment measures that are strikingly at odds with notions of voice as part of active citizenship and democratic rights of young people. Fielding (2004) warns that the manipulative incorporation of student voice simply "leads to the betrayal of hope, resigned exhaustion and the bolstering of an increasingly powerful status quo" (p. 296). Such every day institutional co-option of student voice to control young people is commonplace in the control society.

$$
\text { music really does keep me sane }
$$

In this paper, I seek to engage with the over-coded notions of student voice and agency through experimenting with data collected from one particular alternative schooling context: a boutique urban senior secondary music college in Brisbane, Australia, called Harmony High. I propose the use of music as a performative methodology that might offer an opening up of student voice, rather than closing it down and limiting it to a simplistic politics of emancipation. The reframing of student voice is mobilised through an experimental musical performance in the interrogation of alternative schooling and its placement within the wider education machine.

someone is thinking the same thing you are

\section{Neoliberal accountabilities and student voice}

$$
\text { it's just that music captivates me }
$$

Education policy-making in the contemporary neoliberal context tends to produce reductive, oversimplified and essentialist notions of classrooms, teachers and students. An emphasis on data that provides for 'evidence-based practice' permeates the education machine and limits the boundaries of what can be known. Implications of neoliberalism in education are multiple and diverse (Connell, 2013a), including the centralisation of educational decision-making, implementation of high-stakes testing regimes and performance-based accountability measures, as well as the homogenising of curriculum and pedagogy through curriculum initiatives. Neoliberalism has powerful effects across all levels of schooling in Australia, obscuring the damaging forces of the market and entrenching the 'very mechanisms of distinction that widen educational inequality' (Francis and Mills, 2012, p. 252). Apple (2012) argues that the marketisation of education not only reproduces inequalities already present but actively works to create new forms of inequality through pressures for common culture and reductive accountability systems. For example, this can be observed in the USA via the introduction of the Common Core, and in Australia through interrogations of the National Assessment Program: Literacy and Numeracy (Thompson and Cook, 2012).

\footnotetext{
$\sim I ' m$ treated like the rest of the class
} 
There has been a neoliberalisation of educational systems in places such as the USA, UK and Australia (see Apple, 2012; Connell, 2013a; Francis and Mills, 2012; McGregor and Mills, 2011) built on the premise of surveillance, competition, ranking and classification as drivers of education 'reform' and continuous 'improvement'. Market-measures, discourses of 'choice' and individual merit permeate the narratives that are paraded in policy and media treatments of schools and schooling alongside league-tables, high-stakes testing of literacy and numeracy both on the national and international level, which work to legitimise particular neoliberal truths (Connell, 2013a) of what works in education. In this homogenised educational landscape, external regulation works as a method of control, stipulating the limits of knowledge and behaviour that are acceptable (Davies, 2009). Within such regulated systems of control, other modes of production are rendered illegitimate and beyond consideration. This becomes problematic for students who are already disenfranchised in schooling systems that are experiencing widening inequality and greater disparity (Connell, 2013b). It further widens the gap in access and educational opportunities between those afforded positions of privilege and those consigned to disadvantage and marginalisation.

\section{$\sim$ I'm a bit more motivated to succeed}

Neoliberalism marketises everything, including the commodification of education and its institutions becoming products that serve the market (Apple, 2012). Deleuze $(1992$, p. 7) describes this as a growing emphasis on 'continuous forms of control, and the effect on the school of perpetual training, the corresponding abandonment of all university research, the introduction of the "corporation" at all levels of schooling.' As a result, schools become sites of social inequality reproduction, where alternative knowledges and ways of being are actively suppressed and collective social responsibility gives way to individual neoliberal subjectivities (McGregor, 2009). Under such a regime, Davies $(2005$, p. 9) warns that 'the neoliberal subject becomes both vulnerable and necessarily competitive, competition being necessary for survival.' Students and teachers work daily in ways that serve to further entrench their own positions within a system that rewards individual entrepreneurship and markets rather than seeking to address issues of social justice, equity and access in education.

\section{I've got something to strive for}

Youdell (2011, p. 16) makes a compelling case for educators and education researchers to engage in everyday struggles and resistances in order to 'shift what and whose knowledge counts and what and whose knowledge is silenced, discarded or erased', thus seeking to transform pedagogic relationships. These acts of resistance work to trouble who and what teachers and students are and might be, although they may also raise particular dangers (such as employment termination or expulsion) for teachers and students, particularly those from non-privileged backgrounds. Part of the troubling of voices and accountabilities in neoliberal politics requires setting up new spaces of refusal. Davies (2005) explains that in order to refuse these conditions we must first be aware of how we are spoken into existence through our discourses in order to fracture and find fault lines into which new discourses and subjectivities might be formed. The next section of this paper seeks to take up Davies' call to create a refusal space in order that student voices might be able to sing a different song to that currently made available through neoliberal education policy production.

$\sim$ I feel pretty successful at the moment 


\title{
Creating refusal spaces where voices might sing
}

\author{
every day I'm learning something new
}

Lather and St. Pierre (2013, p. 631) make a call for refusing the neo-positivist and neoliberal scientism that bounds education research by setting up new concepts and spaces of inquiry. They ask us to consider 'whether we have become so attached to our creation - qualitative research that we have come to think it is real. Have we forgotten that we made it up? Could we just leave it behind and do/live something else?' It is precisely this intent that underlies my desire to work productively with difference through the musical affective mode. Can refusal be musical? Through unsettling the 'taken-for-granteds' in qualitative inquiry, including the construction of research problems, data collection and analysis, along with the very ideas of data, research and arts, perhaps it is possible to put inquiry to work through music in messy and entangled engagements that produce something different for education research. In this paper, I attempt to take up a postqualitative musical research method that troubles the habits of separation, neutrality, and impartiality of more restrictive methodological systems. In doing so, I hope to provide a counterpoint to the narrowing refrains of student voice in education research.

\section{〜 sometimes I find it really hard to relate}

Lather and St. Pierre (2013) speak of qualitative research as being in a close relation with neopositivism, buying into the metanarratives of big data, metrics and replicability that permeate the research landscape. It is here where I place music as an irruption, taking up Koro-Ljungberg and MacLure's (2013) challenge to work with the multivocality of research data. My attempt is to create what Deleuze (1994) might call a new image of thought, one that rejects common sense for the affective powers of aesthetic sense. However, scholars such as Daza and Gershon (2015) warn against the hegemony of the ocular gaze, suggesting a more affective, multisensory and embodied research-creative practice. I think this plays into St. Pierre's (2004) argument that there is a critical need for new concepts. This experiment in creating a refusal space through song is about playing at the edges of voice in order to consider its performative dimensions, expressive power, tensions, dissonances and counterpoints (Jackson, 2003).

maybe that's just my personality

The political work of postqualitative research is in its refusal to be complicit in the microfascist enactments of research that attempts to conform, comply and complement taken-for-granteds and common sense understandings of the world. As Koro-Ljungberg $(2012$, p. 808) explains, 'in the absence of complication, responsibility, creativity, and surprise, confirmatory and perfunctory research might serve as the desired or required default thereby pushing aside more generative research models.' Creating a space for voices to sing requires the rejection of common sense, the riskiness and daring of heading somewhere where other voices fear to speak. This is powerful work, because it allows for what Braidotti $(2008$, p. 27) refers to as cartographies of subjectivity, 'which adequately reflect the processes of flows, fragmentation, mutual interdependence, and mutations that mark our era.' While I am not presenting a definitive map of how music works with student voice, the inquiry is cartographic (Gershon, 2013a) in the sense that the performance of data is at once musical and vocal.

\section{～I think I've reengaged this year}

I turn to the post-ontologies that MacLure (2013, p. 658) invites, where music works as a product and producer of materialist research that refuses the 'hierarchical logic of representation'. In doing 
so, I acknowledge St. Pierre's (2011, p. 614) claim that 'we and the world are products of theory as much as practice, and that putting different theories to work can change the world.' Here, I seek to offer music as a productive method for re-framing the notion of student voice, one that goes beyond simplistic binaries or emancipatory politics of critical pedagogy that places student voice at its heart.

last year I just wasn't completely focused

\title{
An introduction to music as concept and method
}

\author{
I spent a year not doing anything
}

What does it mean to think in music? If we remove the privileging of language in thought and replace it instead with music, what might that do? Can the musical mode provide us with different ways of knowing and understanding that the linguistic mode is unable to? Can music actually be even considered thought or is its affective domain much more important than the cognitive? I take heart from Campbell $(2013$, p. 131), who says, 'music, as the other arts, is not subjected to philosophy by Deleuze. Music assumes the condition of thought, new thought, albeit in the realm of the percept rather than the concept.' In this paper I show how I have made use of music as a productive part of my research repertoire and examine how it might link into student voice and how power, relations and pedagogic encounters might be understood within school sites. Music as method draws on the work of Deleuze and Guattari alongside musicology as a non-representational mode of interrogating student voice and agency.

\section{I went through a couple of mental health wards}

First, music as method relies upon the intuitive, affective domain of human knowing. As Deleuze (1991, p. 27) explains, 'intuition leads us to go beyond the state of experience toward the conditions of experience. But these conditions are neither general nor abstract. They are no broader than the conditioned: they are the conditions of real experience.' Music is very real, even if words fall apart when we attempt to describe it. St. Pierre (2011, p. 621) connects into this sense, where she says that 'words are always thinkable, sayable, and writable only within particular grids of intelligibility, usually dominant, normalised discursive formations.' Given that, what do we do when words fall over, on in the case of music, are rendered meaningless? Can we move beyond the linguistic mode?

\section{I didn't really fit into the normal school curriculum}

The limitations of linguistic representational modes of knowledge is a distinct problematic, and one which the arts have struggled with perennially. There have been some developments, particularly in noise and sound studies, which have some connections to music (for example, see: Hulse \& Nesbitt, 2010; Moisala et al., 2017; Sterne, 2012; Young, 2015), where non-vocal sound and music are explored through a range of onto-epistemological positions. For instance, Gershon (2013a, p. 40) argues that 'sounds perhaps enunciate that which text and image cannot.' However, qualitative inquiry still generally privileges 'the voice' for its linguistic and semiotic meaning-making systems. MacLure (2013, p. 660) suggests that language must be 'deposed from its god-like centrality in the construction and regulation of worldly affairs, to become one element in a manifold of forces and intensities that are moving, connecting and diverging.' This is where music comes in and produces difference in ways that language never can. As Deleuze explains in his conversations with Parnet (2002, p. 33), 'is it by chance that music only knows lines and not points? It is not possible to produce a point in music. It's nothing but becomings without future or past. Music is an anti- 
memory. It is full of becomings.' This is important as musical-becomings are neither beginnings nor ends as such, but lines of flight that are constantly seeking to escape the trappings that we enclose our experiences within.

\section{I don't conform to anything}

Perhaps one of the most powerful aspects of music is that it is affective, non-representational and non-cognitive. Music has its own internal logic, an ordering of space and time that is both anathema and affirming of language. Perhaps Deleuze (2003, p. 56) explains it best, when he claims that, 'music attempts to render sonorous forces that are not themselves sonorous.' It is in the sound waves, the molecular movements of atoms in air-ear-brain-lungs-face-feet-backpack, that music is made real. To elucidate this point, he goes on to say that:

Music traverses our bodies in profound ways, putting an ear in the stomach, in the lungs, and so on. It knows all about waves and nervousness. But it involves our body, and bodies in general, in another element. It strips bodies of their inertia, of the materiality of their presence: it disembodies bodies (Deleuze, 2003, p. 54).

\section{traditional ways of schooling don't really work}

In his book, Music after Deleuze, Campbell (2013, p. 1) explains that, 'music is for Deleuze absolutely implicated with thought, and at its best, is indicative of new directions for thought that are arguably uncapturable in any other medium.' Without wishing to get embroiled in an analysis of modes and mediums of human knowing, thought and understanding, I wish to pick up here the idea of 'capturing', without conflating it with 'representing'. That is, the capturing of thought through music is not some kind of quasi-humanist idea of knowing universal truths or recording the unalterable universe that is 'out there'. Rather, the capturing of thought that is musical requires an understanding of the musical configurations of knowledge, which Kielian-Gilbert (2010) describes as necessary when entering a Deleuzoguattarian philosophy of radical immanence.

\section{/ just wasn't interested in school and what teachers had to say}

This is where music as method comes in; an attempt to work within the space between music as pure affect and language as cognitive response. Music as method recognises that existence is the polyphony of vibrations - everything resonating and harmonising with everything else (Gershon, 2013b), or as Szekely (2003, p. 121) says, presenting 'itself to us as simply, and unintentionally, productive, not dialectical as producing certain tendencies and intensities.' Music, in this sense, might be considered as a body without organs (Deleuze \& Guattari, 1983), that is, a virtual assemblage that produces immanent vitalities that cannot be captured in any other form. Instead it becomes an affective, rather than cognitive, knowing. Deleuze and Guattari (1987) describe this as the imperceptible appearing as sound molecules as a molecular becoming allows the inaudible to be captured.

\section{I've never really done well with people trying to assert their authority}

Campbell (2013, p. 42) elucidates the musical becomings of music when he explains that 'musical sound is only one component among others within a musical assemblage, since it is formed equally from literary, artistic, philosophical and many other milieus, the elements of which are assembled to form an expressive musical territory', or what Deleuze and Guattari (1987) call the refrain. A properly musical method then, needs to account for the milieu, not just music as rarefied art form as transcendental, which has been the tendency of traditional Western musicology. The Indonesian gamelan is more relevant to music as method than the symphonic orchestra. Deleuze and Parnet 
(2002, p. 28) explain this as a collective assemblage of enunciation as opposed to the speaking subject. A musical becoming allows for echoes and relays, for refrains and intermezzos 'as sources of creation'.

\title{
and their pseudo-intellect
}

Music becomes a productive and affirming force that flies along particular lines, unconstrained and (un)knowable. One of the productive flows of music as a milieu is in its ontology of change (KielianGilbert, 2010), where music becomes a focus for actualising the effects of becoming, a way of understanding the ebb and flow of life. There is a profound power in music, which Deleuze (2003) describes as rhythm. At its most basic, music as method provides an affective methodology for affirming the rhythms, and musicality, of life and becoming. Music sits both inside and alongside experience, producing the sonorous qualities of onto-epistemological becoming.

$$
\text { adults in general forget what it's like to be a child }
$$

\section{Troubling student voice through music}

\author{
they forget that it's not fun to be yelled at every day
}

When researchers, educators, politicians and the media refer to voice in relation to young people in schools, there is a tendency to rely on binary understandings of power, relationships and what it means to construct the citizen-subjects of teachers and students within those spaces. Yet, taking on Mazzei and Jackson's (2012, p. 745) appeal to 'challenge simplistic treatments of voice in qualitative research that beckon voices to "speak for themselves" or that reduce complicated and conflicting voices to analytical "chunks" that can be interpreted free of context and circumstance', requires a particular political stance and epistemological reasoning. They go on to decry the conventional approaches to research that privilege voice as speaking transcendental, universal truths and presenting versions of real experience. So, what then is involved in a musical treatment of student voice? Through music, student voice becomes something different, a productive focus of flows and anticipations that precede and proceed to move in rhythms, intensities, frequencies and durations.

\section{I never wanted to go to school}

Music as method allows for musical enunciations that reject the boundaries between art forms, genres and conventional narrative (Campbell, 2013), in order to allow for play, multiplicity, deterritorialisation and experimentation. At the same time, as Deleuze and Guattari (1987) warn, the musical refrain is itself a form of re-territorialisation, where new (and old) boundaries are formed. I understand that voices of participants and the 'data' that are collected through our research encounters cannot be essentialised or presented as an objective version of true subjects that are being captured without interference. As Mazzei (2013) explains, we cannot separate ourselves from the enactments of data and the messy entanglements of researcher-dataparticipants-theory-analysis that we produce. Perhaps there is some hope in what Deleuze (1997, p. 109) refers to as the minor use of major language - in this instance, where music minorises the language, by forming 'dynamic combinations in perpetual disequilibrium.' It seems that music is primarily fulfilling two functions - the ordering of chaos through rhythm and the virtual-actual performances of difference (Deleuze, 1994). Campbell $(2013$, p. 33) claims that 'the imperative of Deleuzian difference is that we think music in a new way, no longer focusing on it as something static, unchanging, eternal, always the same, but as dynamic, changing and always shifting.' It is in 
the shifting of music, the modality and modulation, where powerful affects can be felt. They are the sudden gut-wrenchers that appear out of the melodic interlude - the weaving, harmonic interplay of forces that are beyond cognitive reckoning and into an affective knowing.

$$
\text { I don't really believe in the school system }
$$

There is the question of what this means to qualitative education research. And the problem of education research is that it seems to be framed by the imperative for continuous improvement agenda in policy, which limits the creative potential that is offered up by productive difference in research. It doesn't seem to help when Lather (1992, p. 96) says that the 'awareness of the complexity, contingency, and fragility of the practices we invent to discover the truth about ourselves can be paralysing', yet this fragility itself contains the potential of music. Davies $(2005, \mathrm{p}$. 2) takes up this challenge, where she explains critique as being risky work as it 'requires a kind of daring, a willingness to envisage the not yet known and to make visible the faults, the effects of the already known.' There is a real political motive in this when it comes to (re)imagining schools in the interests of the most disadvantaged (Connell, 1993).

\section{I was pretty unhappy at my old school}

Music can be an inventive act of method - it does not seek to uncover what exists in terms of student voice, or any other potential phenomena, although it is also just as likely to form stratified territories that trap difference (think of pop music as one example of the musical refrain). However, as Deleuze (1991, p. 15) explains, 'invention gives being to what did not exist; it might never have happened.' Therein lies the potential of music as a method: it produces something that might never have been there otherwise; the potential for it to act upon the world is only known through the productive capacities that it is afforded. One such affordance is how 'music's discerning aesthetic becomes multidimensional, configuring the social, ethical, and political' (Kielian-Gilert, 2010, p. 200). There is something deeply political and personal about music that can only be understood through an affective musical mode. Koro-Ljungberg (2012, p. 808) explains that 'methods, methodological events, or decision points do not follow a linear progression, but the intervals and voids between and beyond the points are as significant as the events themselves.' Music is formed of intervals, lines and becomings that are events which can open up meaning. This fits with Mazzei and Jackson's $(2012$, p. 745$)$ call to use theory in an 'effort to refuse the romance of voice as we attempt to open up, rather than foreclose, meaning.' How then, might music open up voices and meaning?

\section{I felt like I was kept in a machine}

Music is, after all, organised sound. As such, 'bringing the noise is part of the complex materiality of bodies where modes of performative expression, including music, allow for a transgressive (re)imagining of experience' (Riddle, 2013b, p. 47). Perhaps it is here that we are able to make the passage from noise to voice and through these voicings come to a place where students can sing songs that would be otherwise unheard. There are possible implications for how these pedagogical encounters might be understood differently in classrooms along with the potential for curricular, policy and pedagogical reform. Similar to Gershon's (2013b, p. 261) work with sonic cartographies and vibrational affects, I am interested in how music experimentation might work in an 'affectively embodied fashion that is simultaneously theoretically and materially resonant-vibrations that affect and are in turn affected by others' nested layers of resonances'.

$$
\text { like kept in a box }
$$




\title{
Singing one song with many voices: or can voices even be heard?
}

\author{
I have to see something and I have to do it to learn
}

In this paper, I have established a conceptual framing of music as method in order to perform a particular empirical experiment. I have drawn upon data collected from Harmony High, an independent music industry-connected college that I have been working with closely with a colleague over the past three years. We have published some papers relating to the work that we have been engaging with at the school with different focuses on philosophies of leadership (Riddle and Cleaver, 2013), the centrality of music (Cleaver and Riddle, 2014) and the politics of schooling (Riddle and Cleaver, 2015). The main point of difference here is in my treatment of the data through a musical lens alongside a postqualitative approach to methodology.

everything was wrong with my old school

The data were collected as series of audio-recorded conversations with students during 2013, transcribed and then assembled here using a polychoral arrangement. The assembled lyrics, threaded throughout this entire paper, are neither thematically-analysed, nor are they coded and categorised into cognitive chunks that are recognisable through the linguistic mode. Rather, they are assemblages of utterances by a number of students over a range of conversations, gathered and massaged into a form that flows much like the lyrics of any song might. There is a simultaneous treatment of voice as both choral and polyvocal, alongside a univocity, or singular actualisation of voice.

$\sim$ we didn't get to learn anything that we wanted to learn

Rather than reading these lyrics, objectively and with a seeking eye for thematic alignment, try singing. Start the paper again, and this time ignore the research text and focus only on the polychoral peroformance. It is musical, despite being presented on this limited page as a twodimensional verse (due to restrictions with ethical clearance and permissions to use the original recordings other than for transcription purposes). You only have to sing along to know it, not cognitively, but as Deleuze says, through putting an ear in your stomach and opening up to musical affective knowing.

\section{the stuff we study I actually care about}

The idea behind this particular treatment of student voice is an attempt to break the bounds of an assumed univocity that comes from researching student voice. Instead, the assemblages are broken and reformed in new ways that produce something different, forming new sonic cartographies (Gershon, 2013a). In doing so, the virtual potentiality is made actual through a particular performance of voice. This is not to say that there is some underlying real or truth that becomes discovered and solves the research question. Deleuze and Parnet $(2002$, p. 133) argue that musical assemblages provide codes and territories, constraints and apparatuses of power, that we are then able to explore through a musical becoming. It is contingent, fraught and could fall apart at any moment.

/ love being here; it's great

The musical assemblage performed throughout this paper is via the avatar of 'the Harmony High student'. This is done through the assembling of various statements made by different students across the course of multiple times and places. If I were to say 'who' they were, by using the 
carefully-chosen pseudonyms, I might say that these are the voices of Jeremy, Alfred, Eli, Bec, Cora, Ari and James. And yet, they are not those voices at all because I have taken them out of the original conversational contexts, manipulated their placements and timings in order to construct an entirely new voice. I have made use of prosody to inform the construction of verse that is then represented in this paper. The term avatar is quite useful, as it invokes the enactment of a particular series of virtuals, rather than establishing a singular actual representation of the real. Is this similar to the choir that raises individual voices together in a seemingly unified harmony? Even this is an illusion, given that each vocalisation lies somewhere roughly around the frequency range that we might call a 'note'. There is no such thing as singing perfectly in tune together.

$$
\sim \text { it doesn't feel like school }
$$

Returning then to the notion of how student voice might be troubled in this setting, I take up Mazzei's (2013, p. 735) point that 'voice in postqualitative inquiry becomes an entanglement of desires, intensities, and flows.' It seems that music provides a productive desiring space in which to enact and entangle these flows - it is at once affective and affirming. Yet, Deleuze (1997, p. 159) explains that 'sometimes, finally, the voice manages to overcome its repugnances, its loyalties, its ill will, and, carried along by the music, it becomes speech, capable in turn of making a verbal image, as in a German lied, or of itself making the music and colour of an image, as in a poem.' What about the immanence of the 'jam session' in a band room or the flows and intensities that arise from a freejazz improvisation? Are these any more or less structured and ordered temporal-spatiality out of the chaos? An argument could be made that these are voiced performances of the very entangled desires, intensities and flows that Mazzei (2013) and Deleuze (1997) are referring to.

\section{there's a lot of respect between each other}

Mazzei (2013, p. 734) takes it a little further, explaining that voice 'cannot be thought as emanating "from" an individual person. There is no separate, individual person, no participant in an interview study to which a single voice can be linked - all are entangled.' As such, it is as legitimate for me to assemble a song lyric with a free-generic musical entanglement that I leave up to the reader, as it would be for me to present my data in a stratified quasi-objective manner as untreated 'data'. To do otherwise would be to fall into the trap of seeking research findings that are 'evidence based' and concerned with 'what works'. Instead, a musical method here seeks simply to disrupt the taken-forgranted notions of student voice, and to instead present it as an entanglement.

\section{sometimes it feels like a family}

The utterances of students from Harmony High have been transmuted into a collective assemblage of enunciation (MacLure, 2013), where the collective, social voices are not coming from within rational neoliberal subjects but are formed from elsewhere, from the polychoral subjective voice. The practice here is to work with language creatively that goes beyond style into diverse difference, which Deleuze (1997, p. 55) explains allows language to be 'pushed to its limit, to music or silence.' As with Jackson's (2003) rhizovocality, this attempts not to make voice meaningless, but rather to express its contingency as it produces itself.

\section{you're more than just a student}

Taking heed of Deleuze's (1995, p. 163) argument that 'philosophy is truly an unvoiced song, with the same feel for movement that music has', there is a movement produced through music that is an immanent act of deterritorialisation. In this particular case, the refrain being interrogated is that of student voice and the reified approaches to its use in education research that seeks an emancipatory 
politics of transcendence. I hope that, like Koro-Ljungberg and MacLure (2013, p. 221), that in the work of this paper, I have left the reader with some sense of 'unsettlement, discomfort, and uncertainty; with a creative confusion related to what do you do with the ideas' that have been shared through offering a method of producing difference; an affective, musical becoming. In doing so, voice is shown to be partial, contingent and inherently unstable (Jackson, 2003) as meaning itself is unable to be captured or transcended.

you're actually a real human being

\section{References}

Apple, M. W. (2013). Can education change society? New York: Routledge.

Apple, M. W., \& Beane, J. A. (1999). Democratic schools: Lessons from the chalk face. Buckingham: Open University Press.

Braidotti, R. (2008). Of poststructuralist ethics and nomadic subjects. In M. Düwell, C. RehmannSutter, \& D. Mieth (Eds.), The contingent nature of life: bioethics and the limits of human existence (Vol. 39). Dordrecht: Springer. https://doi.org/10.1007/978-1-4020-6764-8_3

Campbell, E. (2013). Music after Deleuze. London: Bloomsbury.

Cleaver, D., \& Riddle, S. (2014). Music as engaging, educational matrix: Exploring the case of marginalised students attending an 'alternative' music industry school. Research Studies in Music Education, 36(2), 245 - 256. https://doi.org/10.1177/1321103X14556572

Connell, R. W. (1993). Schools and social justice. Toronto: Our Schools Ourselves Education.

Connell, R. W. (2013a). The neoliberal cascade and education: an essay on the market agenda and its consequences. Critical Studies in Education, 54(2), 99 - 112. https://doi.org/10.1080/17508487.2013.776990

Connell, R. W. (2013b). Why do market 'reforms' persistently increase inequality? Discourse: Studies in the Cultural Politics of Education, 34(2), 279 - 285. https://doi.org/10.1080/01596306.2013.770253

Davies, B. (2005). The (im)possibility of intellectual work in neoliberal regimes. Discourse: Studies in the Cultural Politics of Education, 26(1), 1 - 14. https://doi.org/10.1080/01596300500039310

Davies, B. (2009). Deleuze and the arts of teaching and research. International Journal of Qualitative Studies in Education, 22(5), 626 - 631. https://doi:10.1080/09518390903143650

Daza, S., \& Gershon, W. (2015). Beyond ocular inquiry: sound, silence, and sonification. Qualitative Inquiry, 21(7), 639-644. https://doi:10.1177/1077800414566692

Deleuze, G. (1990). The logic of sense (M. Lester, Trans.). London: The Athlone Press.

Deleuze, G. (1991). Bergsonism (H. Tomlinson \& B. Habberjam, Trans.). New York, NY: Zone Books.

Deleuze, G. (1992). Postscript on the societies of control. October, 59, 3 - 7.

Deleuze, G. (1994). Difference and repetition (P. Patton, Trans.). London: The Athlone Press.

Deleuze, G. (1995). Negotiations 1972 - 1990 (M. Joughin, Trans.). New York, NY: Columbia University Press.

Deleuze, G. (1997). Essays critical and clinical (D. Smith \& M. A. Greco, Trans.). Minneapolis, MN: University of Minnesota Press.

Deleuze, G. (2003). Francis Bacon: the logic of sensation (D. W. Smith, Trans.). London: Continuum.

Deleuze, G., \& Guattari, F. (1983). Anti-Oedipus: Capitalism and schizophrenia (R. Hurley, M. Seem, \& H. R. Lane, Trans.). Minneapolis, MN: University of Minnesota Press. 
Deleuze, G., \& Guattari, F. (1987). A thousand plateaus: Capitalism and schizophrenia (B. Massumi, Trans.). Minneapolis: University of Minnesota Press.

Deleuze, G., \& Parnet, C. (2002). Dialogues II (H. Tomlinson \& B. Habberjam, Trans.). London: Continuum.

Fielding, M. (2004). Transformative approaches to student voice: theoretical underpinnings, recalcitrant realities. British Educational Research Journal 30(2), pp. 295-311. https://doi.org/10.1080/0141192042000195236

Francis, B., \& Mills, M. (2012). Schools as damaging organisations: instigating a dialogue concerning alternative models of schooling. Pedagogy, Culture \& Society, 20(2), 251 - 271. https://doi:10.1080/14681366.2012.688765

Gershon, W. (2013a). Sonic cartography: mapping space, place, race, and identity in an urban middle school. Taboo, 13(1), 21-45.

Gershon, W. (2013b). Vibrational affect: sound theory and practice in qualitative research. Cultural Studies $\leftrightarrow$ Critical Methodologies, 13(4), 257-262. https://doi:10.1177/1532708613488067

Hulse, B., \& Nesbitt, N. (Eds.). (2010). Sounding the virtual: Gilles Deleuze and the theory and philosophy of music. Surrey: Ashgate.

Jackson, A. Y. (2003). Rhizovocality. International Journal of Qualitative Studies in Education, 16(5), 693 - 710. https://doi:10.1080/0951839032000142968

Kielian-Gilbert, M. (2010). Music and the difference in becoming. In B. Hulse \& N. Nesbitt (Eds.), Sounding the virtual: Gilles Deleuze and the theory and philosophy of music (pp. 199 - 225). Surrey: Ashgate.

Koro-Ljungberg, M. (2012). Researchers of the world, create! Qualitative Inquiry, 18(9), 808 - 818. https://doi:10.1177/1077800412453014

Koro-Ljungberg, M., \& MacLure, M. (2013). Provocations, re-un-visions, death, and other possibilities of "data". Cultural Studies $\leftrightarrow$ Critical Methodologies, 13(4), 219-222. https://doi:10.1177/1532708613487861

Lather, P., \& St. Pierre, E. A. (2013). Post-qualtitative research. International Journal of Qualitative Studies in Education, 26(6), 629 - 633. https://doi.org/10.1080/09518398.2013.788752

MacLure, M. (2013). Researching without representation? Language and materiality in postqualitative methodology. International Journal of Qualitative Studies in Education, 26(6), 658 - 667. https://doi:10.1080/09518398.2013.788755

Mazzei, L. A. (2013). A voice without organs: interviewing in posthumanist research. International Journal of Qualitative Studies in Education, 26(6), 732 - 740. https://doi:10.1080/09518398.2013.788761

Mazzei, L. A., \& Jackson, A. Y. (2012). Complicating voice in a refusal to "let participants speak for themselves". Qualitative Inquiry, 18(9), 745 - 751. https://doi:10.1177/1077800412453017

McGregor, G. (2009). Educating for (whose) success? Schooling in an age of neo-liberalism. British Journal of Sociology of Education, 30(3), 345 - 358. https://doi:10.1080/01425690902812620

McGregor, G., \& Mills, M. (2012). Alternative education sites and marginalised young people: 'I wish there were more schools like this one'. International Journal of Inclusive Education, 16(8), 843 - 862. https://doi:10.1080/13603116.2010.529467

McLeod, J. (2011). Student voice and the politics of listening in higher education. Critical Studies in Education, 52(2), 179 - 189. https://doi:10.1080/17508487.2011.572830

Mockler, N., \& Groundwater-Smith, S. (2014). Engaging with student voice in research, education and community: beyond legitimation and guardianship. Switzerland: Springer.

Moisala, P., Leppänen, T., Tiainen, M., \& Väätäinen, H. (Eds.). (2017). Musical encounters with Deleuze and Guattari New York, NY: Bloomsbury. 
Riddle, S. (2013a). Looking for madness in the method: Rhizo-becoming in educational research. In W. Midgley, K. Trimmer, \& A. Davies (Eds.), Metaphors for, in and of Education Research (pp. 131 - 144). Cambridge: Cambridge Scholars Publishing.

Riddle, S. (2013b). Youth as rhizome: music, machines, and multiplicities. Social Alternatives, 32(2), $45-48$.

Riddle, S., \& Cleaver, D. (2013). One school principal's journey from the mainstream to the alternative. International Journal of Leadership in Education, 16(3), 367 - 378. https://doi.org/10.1080/13603124.2012.732243

Riddle, S., \& Cleaver, D. (2015). Speaking back to the mainstream from the margins: Lessons from one boutique senior secondary school. In K. Trimmer, A. Black, \& S. Riddle (Eds.), Mainstreams, margins and the spaces in-between: New possibilities for education research (pp. 170 - 182). Abingdon: Routledge.

St. Pierre, E. A. (2004). Deleuzian concepts for education: The subject undone. Educational Philosophy and Theory, 36(3), 283 - 296. https://doi.org/10.1111/j.14695812.2004.00068.x

St. Pierre, E. A. (2011). Post-qualitative research: the critique and the coming after. In N. K. Denzin \& Y. S. Lincoln (Eds.), The Sage Handbook of Qualitative Research (4th ed., pp. 611 - 625). Thousand Oaks, CA: Sage Publications Inc.

Sterne, J. (Ed.) (2012). The sound studies reader. London: Routledge.

Szekely, M. (2003). Becoming-still: Perspectives on musical ontology after Deleuze and Guattari. Social Semiotics, 13(2), 113 - 128. https://doi.org/10.1080/1035033032000152561

Thompson, G., \& Cook, I. (2012). Spinning in the NAPLAN ether: 'postscript on the control societies' and the seduction of education in Australia. Deleuze Studies, 6(4), 564-584. https://doi.org/10.3366/dls.2012.0083

Thomson, P. (2011). Coming to terms with 'voice'. In G. Czerniawski \& W. Kidd (Eds.), The student voice handbook: bridging the academic/practitioner divide (pp. 19 -30). Bingley: Emerald Group.

Thomson, P., \& Gunter, H. (2006). From 'consulting pupils' to 'pupils as researchers': a situated case narrative. British Educational Research Journal, 32(6), 839 - 856. https://doi:10.1080/01411920600989487

Youdell, D. (2011). School trouble: Identity, power and politics in education. Abingdon: Routledge.

Young, M. (2015). Singing the body electric: the human voice and sound technology. Farnham, Surrey: Ashgate. 